\title{
Effect of temperature on adsorption and chromatography of polystyrene macromolecules
}

\author{
Eltekov A.Yu., Eltekov Yu.A. \\ Frumkin Institute of Physical Chemistry and Electrochemistry, Russian Academy of Sciences, Moscow
}

Received 13.09.2018

DOI: https://doi.org/10.17308/sorpchrom.2018.18/608

Study of the effect of temperature on the parameters of adsorption and liquid chromatography of molecules and macromolecules constantly attracts the attention of specialists. The potential benefits of elevated temperature column, particularly enhanced kinetic and transport properties, which are based on the reduction of mobile phase viscosity and increase the diffusion of analyte at high temperature, began to be actively used for the rapid analysis of molecules and macromolecules by chromatographic methods in recent years. It is now recognized that temperature is an important tool to optimize chromatographic parameters, such as retention, selectivity and efficiency, particularly for macromolecules

The effect of temperature on adsorption and liquid chromatography of polystyrene macromolecules on silicas has been investigated by static and .chromatographic methods. The sign and value of the temperature adsorption coefficient depend on many factors, namely, the chemical nature of the solvent, the chemical structure of macromolecules and adsorbent surface chemistry. Thus temperature elevation in the chromatographic system alters the macromolecular coil dimensions and total energy of elution of solvent molecules from the adsorption space of the porous adsorbents. Keeping these factors in view we can find the sign of the temperature adsorption coefficient. Diffusion coefficients increase in proportion to temperature, thus efficiency is usually enhanced, too, as peaks become more narrow. Prospects for optimization of the chromatographic process and, above all, the efficiency of separation of components of mixtures, include the effect of temperature on the adsorption of the components and their retention in the chromatographic column.

Keywords: Liquid adsorption and chromatography, different temperatures, polystyrene standards, macroporous silicas.

\section{Влияние температуры на адсорбцию и жидкостную хроматографию макромолекул полистирола}

\author{
Эльтеков А.Ю., Эльтеков Ю.А.
}

Институт физической химии и электрохимии им. А.Н.Фрумкина РАН (ИФХЭ РАН), Москва

Ранее существовало мнение, что изменение температуры на несколько градусов практически не влияет на адсорбционные характеристики при взаимодействии адсорбирующихся веществ в жидкой фазы. Вероятно, поэтому изучению влияния температуры на параметры адсорбции из растворов и жидкостной хроматографии уделялось мало внимания. В последние годы стал проявляться повышенный интерес к температурным эффектам в адсорбции и жидкостной хроматографии молекул и в большей степени макромолекул полимеров и биополимеров. В представленной работе исследовано влияние температуры на адсорбцию и жидкостную хроматографию макромолекул полистирола на кремнеземных стационарных фазах. Рассмотрены термодинамические и кинетические закономерности поведения макромолекул синтетических полимеров при повышении температуры в порах макропористых гидроксилированных и модифицированных кремнеземных сорбентов. Отмечается, что изменение температуры оказывает влияние прежде всего на термодинамические свойства растворителя, что приводит к увеличению или уменьшению значения коэффициента распределения и изменению знака температурного коэффициента адсорбции. 
Показано, что повышение температуры может приводить к возрастанию адсорбции полимеров из растворов на пористых кремнеземных сорбентах. Это возрастание адсорбции и, по-видимому, доли доступной внутренней поверхности пор кремнеземных адсорбентов с повышением температуры может быть обусловлено ослаблением адсорбционной связи кремнезем - растворитель и десольватацией макромолекулярного клубка с уменьшением его размеров вследствие ослабления взаимодействия между макромолекулами полимера и молекулами растворителя.

Ключевые слова: жидкостная хроматография, стандарты полистирола, макропористые кремнеземы, различие температур

\section{Introduction}

Study of the effect of temperature on the parameters of adsorption and liquid chromatography of molecules and macromolecules constantly attracts the attention of specialists [1-3]. The potential benefits of elevated temperature column, particularly enhanced kinetic and transport properties, which are based on the reduction of mobile phase viscosity and increase the diffusion of analyte at high temperature, began to be actively used for the rapid analysis of molecules and macromolecules by chromatographic methods in recent years [4-8].

Meanwhile, the interest in the liquid chromatography of macromolecules at elevated temperatures is due to the fact that some polymers, e.g. polyolefines, are dissolved at elevated temperatures only, therefore the chromatographic analysis of such polymers can be performed only with the help of a high-temperature chromatography $[3,9,10]$. Thus, it is now recognized that temperature is an important tool to optimize chromatographic parameters, such as retention, selectivity and efficiency, particularly for macromolecules [2, $6,10-12]$. This contribution describes the results of the study of adsorption and liquid chromatography of polystyrene macromolecules from several solutions on silica stationary phases at different temperatures.

\section{Experimental}

Macroporous silicas - silochrom S-80 (specific surface $S=90 \mathrm{~m}^{2} / \mathrm{g}$, average pore diameter $d=60 \mathrm{~nm}$ ) and S-80 modified with trimethylchlorosilane, two silicagels SG-40 $(d=40 \mathrm{~nm})$ and SG-20 $(d=20 \mathrm{~nm})$ and macroporous glass MG-25 $(d=25 \mathrm{~nm})$ were taken as adsorbents. Freshly distilled cyclohexane, ethylbenzene, paraxylene, tetrachloromethane and methylethylketone were used as solvents. All solvents were of «chemically pure» grade. Polymer materials were commercial suspension polystyrene PS1 with polydispersitivity $u=2.5$ and average molecular weigth $M_{w}=280000$ and polystyrene standards of various molecular weights and $u$ less then 1.1.

Under static conditions, adsorption from diluted solutions was studied with the help of an interferometer by changes in the polymer concentration [13-15]. Chromatographic experiments were run using liquid chromatograph Waters-200 (column $1.2 \mathrm{~m}$, particle size $85 \pm 5 \mu \mathrm{m}$ ) and liquid chromatograph LC-1309 (NTO, S-Peterburg, Russia) (column $300 \times 0.5 \mathrm{~mm}$, particles size $5 \pm 2 \mu \mathrm{m})$. The eluent flow rate was $1 \mathrm{ml} / \mathrm{min}$. The overall solvent volume in the column was found by the time of the peak maximum elution on the chromatogram after introduction of a n-nonene solution sample into the column.

\section{Results and discussion}

Fig. 1 shows the adsorption isotherms of polydispersion polystyrene PS1 from diluted solutions in cyclohexane ( $\theta$-solvent), tetrachloromethane and ethylbenzene on silochrom C-80 at 293 and $343 \mathrm{~K}$. 


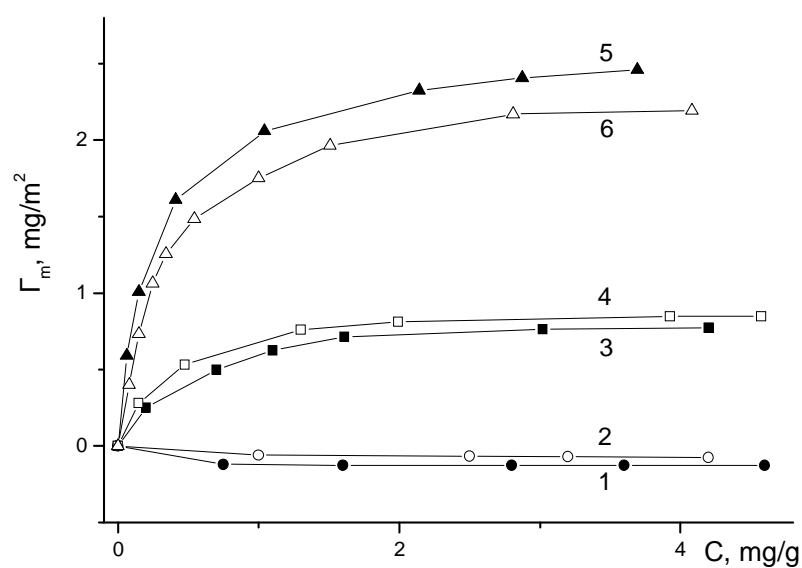

Fig. 1. Adsorption isotherms of PS1 $\left(M_{w}=280000\right.$ and $\left.u=2.5\right)$ macromolecules from dilute solutions in ethylbenzene $(1,2)$ tetrachlormethane $(3,4)$ and cyclohexane $(5,6)$ on Silochrom S-80 at $293 \mathrm{~K}(1,3,5)$ and $343 \mathrm{~K}(2,4,6)$.

Increase in temperature brings down the PS adsorption from solutions in cyclohexane due to greater mobility of macromolecule segments and coil sizes resulting in weaker adsorption bond energy and smaller pore surface accessible for PS. In this case, the competitive ability of solvent molecules to occupy the silica surface is small and does not change.

With PS dissolved in tetrachloromethane whose molecules are little competitive adsorption of PS grows slightly with temperature. Interaction of solvent molecules with polymer and adsorbent in this adsorption system seems to be weakened. Lability of more compacted macromolecular coil increases encouraging greater adsorption of PS under these conditions [3, 13-15].

Adsorption of PS from solutions in ethylbenzene with hydroxylated silica is negative at 293 and $343 \mathrm{~K}$. It should be stressed here that dehydroxylation of the silica surface results in small, but positive PS adsorption values. Ethylbenzene and other aromatic hydrocarbons and their chlorine derivatives compete greatly with PS macromolecules for silane groups on the silica surface and, at moderate temperatures, expel them from the surface almost completely. The molecular mass of PS also influences the temperature adsorption coefficient.

Table 1 contains kitenic and equilibrium parameters of PS1 adsorption from tetrachlormethane solutions on silicagels SG-20 and SG-40 and silochrom S-80.

Table 1. Values of $\Gamma_{m}\left(\mathrm{mg} / \mathrm{m}^{2}\right)$ at equilibrium concentration $c_{p}=4 \mathrm{mg} / \mathrm{g}, D\left(\mu \mathrm{m}^{2} / \mathrm{sec}\right)$ and $E_{a}(\mathrm{~kJ} / \mathrm{mol})$ at 293 and $343 \mathrm{~K}$

\begin{tabular}{|c|c|c|c|c|c|}
\hline $\begin{array}{c}\text { Pore size of Silicas } \\
d, \mathrm{~nm}\end{array}$ & \multicolumn{2}{|c|}{$292 \mathrm{~K}$} & \multicolumn{2}{c|}{$343 \mathrm{~K}$} & \multirow{2}{*}{$E_{a}$} \\
\hline & $\Gamma_{m}$ & $D$ & $\Gamma_{m}$ & $D$ & \\
\hline 20 & 0.18 & 0.01 & 0.30 & 0.06 & 26 \\
\hline 40 & 0.40 & 0.06 & 0.60 & 0.67 & 38 \\
\hline 60 & 0.83 & 0.08 & 0.88 & 3.30 & 54 \\
\hline
\end{tabular}

The diffusion coefficient $D$ was found from the formula

$$
D=K r^{2} / \pi \tau_{0.5}
$$

where $K$ is the particle shape factor equal to $0.3 ; r$ is the particle radius and $\tau_{0.5}$ is the time required for the relative adsorption value $(0.5)$ to be reached. 
The activation energy $E_{a}$ was found through the temperature diffusion coefficient

$$
E_{a}=R T_{1} T_{2}\left(T_{2}-T_{1}\right)^{-1} \ln D_{2} / D_{1}
$$

Kinetic characteristics shown in Table 1 point to activated character of adsorption of PS macromolecules by porous sorbents. Diffusion coefficients increase in proportion to temperature, thus efficiency is usually enhanced, too, as peaks become more narrow $[3,6$, 9-11].

Table 2 contains distribution coefficients $K_{d}$ of macromolecules of polystyrene standards between the mobile and stationary phases in the chromatographic column packed by silochrom C-80 with hydroxylated and silylated surfaces, and paraxylene served as the mobile phase. The distribution coefficient $K_{d}$ of polymer represents the concentration ratio $[14,15]$

$$
K_{d}=c_{s} / c
$$

where $c_{s}$ and $c$ are the concentrations of polymer in surface and bulk phases, correspondingly. In accordance with the definition

$$
c_{s}=\left(\Gamma_{m} \cdot A+v_{a} \cdot c\right) / v_{a}
$$

where $\Gamma_{m}$ is the excess adsorption value, $A$ is the total surface area of the sorbent in chromatographic column and $v_{a}$ is the adsorption volume $\left(\mathrm{cm}^{3}\right)$ of sorbent in chromatographic column.

Then for $K_{d}$ we get

$$
K_{d}=\left(\Gamma_{m} \cdot A / v_{a} \cdot c\right)+1
$$

The ratio $v_{a} / A$ gives the average statistical thickness of the adsorption layer, $\tau=v_{a} / A$, and the ratio $\Gamma_{m} / c$ represents $K_{H}$ - Henry's constant at $c \rightarrow 0$.

Therefore we can write the expressions for $K_{d}(6)$ and (7)

$$
K_{d}=\left(V_{o} \cdot k^{\prime} / v_{a}\right)+1
$$

where $k^{\prime}$-retention coefficient, calculated as $k^{\prime}=\left(V-V_{o}\right) / V_{o}, V$ is the retention volume of polymer, $V_{o}$ is the dead volume of the column.

$$
K_{d}=K_{H} / \tau+1
$$

From Table 2 it follows that at $388 \mathrm{~K}$ adsorption of PS macromolecules takes place

\begin{tabular}{|c|c|c|c|c|}
\hline \multirow{3}{*}{ PS, $M_{w}$} & \multicolumn{4}{|c|}{ Column temperature } \\
\hline & \multicolumn{2}{|c|}{ Hydroxylated surfase } & \multicolumn{2}{|c|}{ Trimethylsilylated surfase } \\
\hline & $293 \mathrm{~K}$ & $388 \mathrm{~K}$ & $293 \mathrm{~K}$ & $388 \mathrm{~K}$ \\
\hline 4800 & 0.92 & 1.2 & 0.85 & 0.82 \\
\hline 171000 & 0.08 & 0.47 & 0.05 & 0.33 \\
\hline 402000 & 0 & 0.34 & 0 & 0.11 \\
\hline
\end{tabular}
on hydroxylated silochrom surface. This is proved by values of $K_{d} \gg 1$ for low molecular PS and the much higher ones (as compared to $K_{d}$ ) for a silochrom surface coverage with trimethylsilyl groups.

Table 2. Values of $K_{d}$ for PS standards on silochrom S-80 at 293 and $388 \mathrm{~K}$, eluentparaxylene.

Comparison of $K_{d}$ values for a trimethylsilylated sample at 293 and $388 \mathrm{~K}$ also shows that with the increasing temperature the macromolecular coil is compacted due to 
weaker interaction with molecules of solvent - aromatic hydrocarbon which results in a greater fraction of pore volume accessible for these macromolecules and, consequently, increased retention volume.

Fig. 2 shows the dependences of $K_{d}$ values on different temperature for two polystyrene standards with molecular masses $M_{w}=8300$ (1) and 195000 (2) on macroporous glass MG-25.

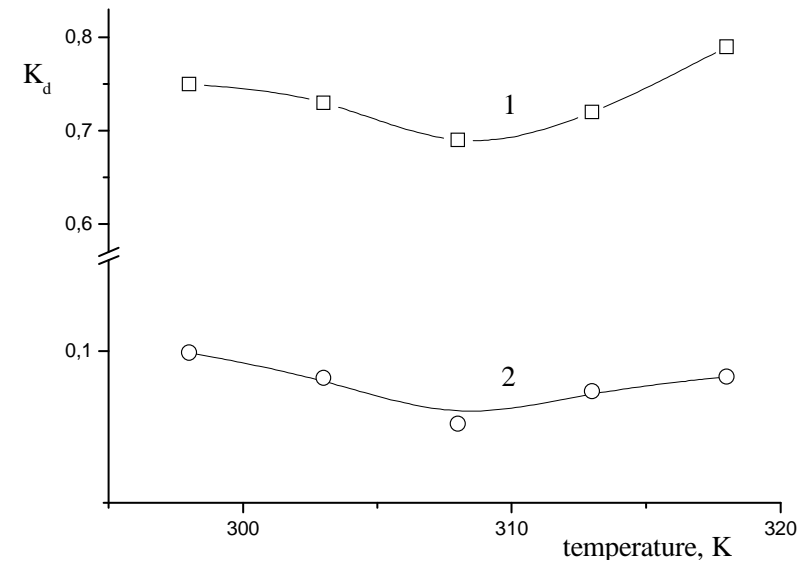

Fig. 2. Dependences of $K_{d}$ values on a temperature for PS standards with $M_{w}=8300$ (1) and $M_{w}=195000$ (2), adsorbent - macroporous glass MG-25, eluent - methylethylketone.

The initial decrease of $K_{d}$ values is due to the diminution of adsoption and intermolecular energy in chromatographic system and the increase of macromolecular coils. The increase of $K_{d}$ values with the increase of temperature is due to the action of adsorption effect.

\section{Conclusion}

The sign and value of the temperature adsorption coefficient depend on many factors, namely, the chemical nature of the solvent, the chemical structure of macromolecules and adsorbent surface chemistry.

Thus temperature elevation in the chromatographic system alters the macromolecular coil dimensions and total energy of elution of solvent molecules from the adsorption space of the porous adsorbents. Keeping these factors in view we can find the sign of the temperature adsorption coefficient.

Diffusion coefficients increase in proportion to temperature, thus efficiency is usually enhanced, too, as peaks become more narrow. Prospects for optimization of the chromatographic process and, above all, the efficiency of separation of components of mixtures, include the effect of temperature on the adsorption of the components and their retention in the chromatographic column.

\section{References}

1. Snyder L.R., Kirkland J.J., Dolan J.W. Introduction to Modern Liquid Chromatography, New Jersey: Wiley, Hoboken, 2010, 89 1p.

2. Teutenberg T. High-temperature liquid chromatography: A user's guide for method de- velopment, Cambridge : RSC Publishing, 2010, $210 \mathrm{p}$.

3. Grebennikov S.F., Eltekov Yu.A. Sorbciya $\mathrm{v}$ polimernyh sistemah. Chast' 2 (Sorption in polymer systems. Part 2), S-Pb.: FGBOUVPO 
SPGUTD, 2014, $286 \mathrm{p}$.

10.Jensen D. S., Teutenberg T., Clark J., Lin-

4. Eltekov A.Y., Findenegg G.H., J. ford M.R., LC GC North Am., 2012, Vol. 30, Chromatogr. A, 2007, Vol. 1150, pp. 236-240. pp. 850-862, 992-998, 1052-1057.

DOI: $10.1016 /$ j.chroma.2007.01.073

11.O'Shea J-P., Qiao G.G., Franks G.V., J.

5. Dietsch O., Eltekov A., Bock H., Gubbins

K.E., Findenegg G.H., J. Phys. Chem. C, 2007,

Colloid Interface Sci., 2010, Vol. 348, pp. 9-23.

Vol. 111, pp. 16045-16054. DOI: 12.Eltekov A.Yu., Sorbtsionnye I khromato10.1021/jp0747656

6. Vanhoenacker G, Sandra P., Anal Bioanal grafichekie protsessy, 2015, Vol. 15, pp. 456Chem., 2008, Vol. 390, pp. 245-248. DOI: 10.1007/s00216-007-1671-7 463.

7. Heinisch S., Rocca J.L., J. Chromatogr. A, 2009, Vol. 1216, pp. 642-658. DOI: 10.1016/j.chroma.2008.11.079

8. Guiochon G., Tarafder A., J. Chromatogr. A, 2011, Vol. 1218, pp. 1037-1114. DOI: 10.1016/j.chroma.2010.12.047

13.Eltekova N.A., Eltekov Yu.A., Rus. J. Phys. Chem. A, 2009, Vol. 83, pp. 2110-2114.

DOI: $10.1134 / \mathrm{S} 0036024409120188$

9. Mekap D, Macko T, Brüll R, Cong R. et al., Polymer, 2013, Vol. 54, pp. 5518-5524. DOI: 10.1016/j.polymer.2013.08.040

Эльтеков Антон Юрьевич - научный сотрудник Института физической химии и электрохимии им. А.Н.Фрумкина РАН (ИФХЭ РАН), Москва, тел. 4959554492
14.Eltekova N.A., Eltekov A.Yu., Protection of metals and phys.chem. surfaces, 2010, Vol. 46, pp. 60-63. DOI: $10.1134 / \mathrm{S} 2070205110010089$

15.Eltekova N.A., Eltekov Yu.A., Protect of metals and phys.chem. surf., 2013, Vol. 49, pp. 261-265. DOI: $10.1134 / \mathrm{S} 207020511303009 \mathrm{X}$

Eltekov Anton Yu. - researcher A.N.Frumkin Institute of Physical Chemistry and Electrochemistry, Russian Academy of Sciences, Moscow, tel. 495 9554492, E-mail: a.eltekov@gmail.com 